AperTO - Archivio Istituzionale Open Access dell'Università di Torino

\title{
Liquidity Constraints, Uncertain Parental Income and Human Capital Accumulation
}

\section{This is the author's manuscript}

Original Citation:

\section{Availability:}

This version is available http://hdl.handle.net/2318/126247

since

Published version:

DOI:10.1080/13504851.2012.750417

Terms of use:

Open Access

Anyone can freely access the full text of works made available as "Open Access". Works made available under a Creative Commons license can be used according to the terms and conditions of said license. Use of all other works requires consent of the right holder (author or publisher) if not exempted from copyright protection by the applicable law. 


\title{
Liquidity Constraints, Uncertain Parental Income and Human Capital Accumulation
}

\author{
Francesco Devicienti and Mariacristina Rossi \\ Department of Economics and Statistics \\ University of Turin \\ and \\ Collegio Carlo Alberto.
}

\begin{abstract}
This study analyzes the effect of parental income variability on investments in education when capital markets are imperfect. Our empirical results show that educational choices might act as a buffer choice when the environment is uncertain.
\end{abstract}

Keywords: Schooling decisions, uncertainty, liquidity constraints

JET classification: E2, I2, O1, R2

Address for correspondence: Mariacristina Rossi, Dipartimento di Scienze Economico-Sociali e MatematicoStatistiche, corso Unione Sovietica 218bis, 10134, Torino (IT).

email: rossi@econ.unito.it

Tel.: +390116706078 


\section{Introduction}

The occurrence of bad shocks might have severe consequences on households' welfare, particularly in developing countries where insurance is scarce. A large body of the literature has focused on the welfare losses caused by shock realizations (Dehejia and Gatti, 2002, and Beegle et al., 2006). These studies mainly focus on how families cope with shocks ex post, i.e. after shocks have happened and uncertainty resolved.

However, the impact of uncertainty on households' decisions can also be studied by observing whether families change their strategies ex ante, i.e. before a shock materializes. A branch of the literature, the so-called precautionary saving literature, has examined how the presence of uncertainty (i.e. income uncertainty) affects consumption/saving decisions (Sandmo, 1970; Deaton, 1992). A key finding is that, assuming convexity of the marginal utility, riskier environments make households defer current consumption in favor of future consumption, by generating a precautionary buffer stock of asset.

Despite the fundamental role of uncertainty for developing countries, its impact on human capital accumulation has not been extensively analyzed. Exceptions are represented by Kodde (1986), Levhari and Weiss (1974) and Pouliot (2006). These studies show that adding uncertainty to human capital returns causes human capital investments to be inefficiently low, even in presence of perfect capital markets. While these studies introduce uncertainty in (future) earnings, the effect of exogenous income uncertainty on schooling decisions has not received much attention, with the recent exception of Fitzimos (2007).

This paper aims at filling this gap, by looking both theoretically and empirically at how exogenous income (such as parental income) uncertainty affects human capital accumulation, in presence and in absence of perfect capital markets.

\section{Theoretical framework}

Following Baland and Robinson (2000) and Pouliot (2006), consider a representative household that maximizes a utility function over two periods, by choosing optimal savings $(s)$ and school time $\left(h_{s}\right)$ of their children. Parental income is exogenously equal to $\mathrm{Y}$ in period one, and stochastic in period two and equal to $\widetilde{A}$ such that:

(1) $E(\tilde{A})=Y$. 
The household's optimization problem is:

$$
\max _{c_{1}, c_{2}} U\left(c_{1}\right)+\beta E U\left(c_{2}\right)
$$

s.t.

$$
c_{1}=Y+\left(1-h_{s}\right) w-s \quad c_{21}=\tilde{A}+f\left(h_{s}\right)+s(1+r)
$$

where $c_{1}$ and $c_{2}$ are household consumption levels at time 1 and $2, r$ the interest rate and $\beta$ the subjective discount factor. The salary earned by children in the labor market is $w$, whereas $f\left(h_{s}\right)$ is the (certain) salary of the grown-up children in period 2. $U$ is a concave utility function.

Putting $w=\beta=1$ and $r=0$ to simplify notation, child schooling is efficient when the marginal return to human capital equals the return on the financial market:

$$
\text { (3) } \quad f^{\prime}\left(h_{s}\right)=1 \text {. }
$$

Hence, stochastic parental income does not affect the efficiency of schooling choices. The reason is that equation (3) holds with and without uncertainty.

The optimal value of child schooling, however, changes if liquidity constraints bind, and households cannot freely borrow their desired amount to keep their consumption smooth over time.

If liquidity constraints are introduced into the model, saving has always to be greater than a certain threshold, $\bar{s}$ :

(4) $s \geq \bar{s}$

The associated Lagrangian function is:

$$
L=U\left(Y+\left(1-h_{s}\right)-s\right)+E U\left(\tilde{A}+f\left(h_{s}\right)+s\right)+\lambda(-\bar{s}+s)
$$


where $\lambda$ is the Lagrange multiplier. In an interior solution, $\lambda$ will be zero, and child schooling efficient.

If optimal saving is smaller than $\bar{s}$, the following inequality holds:

$$
f^{\prime}\left(h_{s}\right)=1+\frac{\lambda}{E u^{\prime}\left(c_{2}\right)}>1 .
$$

This implies that liquidity constrained households are under-investing in schooling, as in Pouliot (2006).

How does this solution compare to that without uncertainty? Let $h_{s}^{C}\left(h_{s}^{U}\right)$ be optimal choices with certainty (uncertainty). The first order conditions for $h_{s}^{C}$ are given by (7) and (8), and by (9) and (10) for $h_{s}^{U}$ :

$$
\begin{aligned}
& u^{\prime}\left(Y-\bar{s}-h_{s}^{C}\right)=u^{\prime}\left(E \tilde{A}+\bar{s}+f\left(h_{s}^{C}\right)\right)+\lambda_{C} \\
& u^{\prime}\left(Y-\bar{s}-h_{s}^{C}\right)=u^{\prime}\left(E \tilde{A}+\bar{s}+f\left(h_{s}^{C}\right)\right) f^{\prime}\left(h_{s}^{C}\right), \\
& u^{\prime}\left(Y-\bar{s}-h_{s}^{U}\right)=E u^{\prime}\left(\tilde{A}+\bar{s}+f\left(h_{s}^{U}\right)\right)+\lambda_{U} \\
& u^{\prime}\left(Y-\bar{s}-h_{s}^{U}\right)=E u^{\prime}\left(\tilde{A}+\bar{s}+f\left(h_{s}^{U}\right)\right) f^{\prime}\left(h_{s}^{U}\right) .
\end{aligned}
$$

Comparing equation (8) with (10), we obtain that school hours in the presence of uncertainty are higher than in its absence. Assuming convex marginal utility, we have:

$$
u^{\prime}\left(Y-\bar{s}-h_{s}^{C}\right)<E u^{\prime}\left(\tilde{A}+\bar{s}+f\left(h_{s}^{C}\right)\right) f^{\prime}\left(h_{s}^{C}\right) .
$$

Notice that, in order to make (11) hold as an equality, it is required that $h_{s}^{C}$ be smaller than $h_{s}^{U}$.

Thus, among non-savers, uncertainty generates a buffer stock through additional education. When the credit market is characterized by financial restrictions, households cannot resort to borrowing to accomplish their preference for consumption smoothing. However, the same constrained households will resort to less borrowing, even if they are allowed to, when they are exposed to a riskier environment. The (latent) reduced need to borrow on the financial market is translated into additional educational investments, whose 
return rate is higher than that on the capital markets. As saving is constrained to equal its lower bound, and additional resources cannot be borrowed, investments in education act as a substitute for saving.

\section{Data and Empirical Results}

Our data derive from a four-round panel survey of households' living standards conducted in Kagera (Tanzania) from 1991 to 1994 (more details are in Alderman et al., 2009).

We select all children aged 7-15 in the last round of the panel, while the first three rounds are exploited to construct our income variability measure.

The following equation is estimated:

$$
H_{i}=\beta_{1} L C_{i}+\beta_{2} \text { uncertainty }_{i}+\beta_{3} L C * \text { uncertainty }_{i}+\beta_{4} X_{i}+v_{i} .
$$

$H i$ stands for child $i$ 's hours of school in the week previous to the interview. In view of the censored nature of the dependent variable, we estimate Tobit models. ${ }^{1} X$ is a set of regressors that include community, household and individual controls.

Similarly to the precautionary saving literature (e.g., Guariglia and Rossi, 2002), we use parental income variability to capture uncertainty surrounding parental income. We construct income variability of the household (uncertainty) as the log of the sample variance of crop loss during the first three rounds of the panel. To derive this measure, we first purge the predicted component of crop loss from its total value, by regressing crop loss on a set of community variable dummies. ${ }^{2}$ The rationale behind the choice of crop shocks as a measure of uncertainty relies on the fact that variability in parental income is mainly determined by the variability in agricultural returns. As agriculture is the main activity in this environment, crop variability is likely to be the main source of exogenous income variability.

\footnotetext{
${ }^{1}$ We also estimated simple Probit models for school attendance obtaining results consistent with those of the Tobit model.

${ }^{2}$ In each wave, each household is asked whether they experienced any crop loss during the previous six months. If the answer is yes, they are also asked the monetary value of the loss.
} 
The key variables of the empirical analysis are uncertainty, an indicator for households potentially liquidity constrained $\left(L C_{i}\right)$ and their interaction.

To capture credit market restrictions, we use a dummy (NoDurables) indicating whether the child's household does not own any durable goods. The absence of durables that may function as collaterals plausibly increases the likelihood of being liquidity constrained in the credit market. We also considered the amount of financial wealth the household owns. Financial assets can be easily converted in cash, potentially providing a more flexible instrument to smooth consumption than durables. NoSavings is our indicator for the absence of household savings.

The results in Table 2, column 1, show that the absence of durable assets is strongly significant in reducing children's schooling. Notice that the presence of uncertainty per se is not statistically significant, in line with the theoretical predictions of the model. However, coherently with the latter, we find that the interaction term has a positive impact on schooling. Among children born to families who are restricted on the credit market, those facing more uncertainty exhibit higher school attendance and hours of schooling than those who live in a less risky environment.

The estimated coefficients can be used to compute various marginal effects, taking into account the interaction term in (13). In particular, we find that the probability of school attendance is 12 percentage points lower for those who are liquidity constrained than for those who are not. Moreover, school intensity can be shown to drop by about 7 hours per week for children belonging to the former group. Hence, the limited access to the credit market generates inefficiently low level of educational investment.

The presence of uncertainty increases schooling, but only for households who are liquidity constrained. For the latter households, doubling the variability of parental income has a sizeable effect, increasing school intensity by about an hour, while the impact on the unconstrained is a non-statistically significant reduction of 0.6 hours. Hence, the presence of uncertainty mitigates the inefficiency due to frictions on the credit markets.

These results are robust to the inclusion of various individual, household and community level controls (column 2). Moreover, the results also hold if liquidity constrained households are identified more restrictively as those with no current savings (column 3). 


\section{Conclusions}

This paper shows that, when households face binding liquidity constraints, an increase in parental income uncertainty leads to a rise in the amount of time children spend in school. Using panel data from rural Tanzania, we provide empirical support for such a theoretical prediction. The results suggest that policy reforms aimed at making the insurance market more efficient - which may adversely affect children's schooling by reducing household uncertainty - should be accompanied by reforms enhancing households' access to credit, thus raising poor households' investments in the human capital of their children.

\section{References}

Alderman, H.J., Hoogeveen and M. Rossi (2009), Preschool Nutrition and Subsequent Schooling Attainment: Longitudinal Evidence from Tanzania, Economic Development and Cultural Change, 57(2), pp. 239-260.

Baland, Jean-Marie, Robinson, James A. (2000). Is child labor inefficient? Journal of Political Economy, 108(4), pp. 663-681.

Beegle, K., Dehejia, R.H., Gatti, R. (2006), Child Labor and Agricultural Shocks, Journal of Development Economics, 81, pp. 80-96.

Deaton, A. (1992), Understanding Consumption. Oxford: Clarendon Press.

Dehejia, R. and R. Gatti (2002), Child Labor: The Role of Income Variability and Access to Credit Across Countries, World Bank Policy Research Working Paper \#2767.

Fitzsimons E. (2007), The Effects of Risk on Education and Child Labor, Economic Development and Cultural Change, 56(1), pp. 1-25.

Guariglia A. and M.C. Rossi (2002) "Consumption, Habit Formation and precautionary saving: Evidence from the British Household Panel Survey", Oxford Economic Papers, 54(1), pp. 1-29.

Kodde A.D. (1986), Uncertainty and the Demand for Education, The Review of Economics and Statistics, 68(3), pp. 460-467.

Levhari D. and Y. Weiss, (1974) The Effect of Risk on the Investment in human Capital, American Economic Review, 64, pp. 950-963. 
Pouliot W. (2006), Introducing uncertainty into Baland and Robinson's model of child labour, Journal of Development Economics, 272 (79), pp. 264-272.

Sandmo, A. (1970), The Effect of Uncertainty on Saving Decisions, Review of Economic Studies, 37(3), pp. 353-360. 
Table 1. Descriptive Statistics. KHDS 1994.

\begin{tabular}{lcc}
\hline Variable & Mean & Standard Deviation \\
\hline School attendance & 0.663 & 0.471 \\
School hours & 18.487 & 16.428 \\
Age (years) & 10.9 & 2.629 \\
Age squared & 125.7 & 57.602 \\
Male & 0.513 & 0.500 \\
Female head & 0.533 & 0.499 \\
Mother's education (years) & 4.167 & 2.877 \\
Father's education (years) & 5.543 & 2.855 \\
Father dead & 0.275 & 0.447 \\
Mother dead & 0.211 & 0.408 \\
No. Of adults in the household & 2.863 & 1.607 \\
No. Of kids & 3.659 & 1.707 \\
Log(household expenditure) & 10.677 & 0.531 \\
No. Of teachers per classroom & 1.398 & 0.509 \\
No. Of blackboards per classroom & 0.719 & 0.219 \\
Secondary school in the village & 1.933 & 0.249 \\
Urban area & 0.157 & 0.364 \\
No durables & 0.469 & 0.499 \\
No savings & 0.192 & 0.394 \\
Uncertainty (logs) & 18.044 & 1.141 \\
uncertainty * No durables & 8.408 & 8.975 \\
uncertainty * No savings & 3.413 & 7.012 \\
\hline Observation & &
\end{tabular}

Observations: 990. 
Table 2. Coefficients of Tobit Models of School Hours.

\begin{tabular}{|c|c|c|c|}
\hline Variable & (1) & (2) & (3) \\
\hline Age & & $\begin{array}{l}18.030 * * * \\
(7.34)\end{array}$ & $\begin{array}{l}17.943 * * * \\
(7.56)\end{array}$ \\
\hline Age squared & & $\begin{array}{l}-0.612 * * * \\
(-5.63)\end{array}$ & $\begin{array}{l}-0.607 * * * \\
(-5.79)\end{array}$ \\
\hline Male & & $\begin{array}{l}0.696 \\
(0.63)\end{array}$ & $\begin{array}{l}0.835 \\
(0.76)\end{array}$ \\
\hline Female head & & $\begin{array}{l}0.596 \\
(0.29)\end{array}$ & $\begin{array}{l}0.672 \\
(0.35)\end{array}$ \\
\hline Mother's education & & $\begin{array}{l}0.538 * * * \\
(2.62)\end{array}$ & $\begin{array}{l}0.519 * * * \\
(2.63)\end{array}$ \\
\hline Father's education & & $\begin{array}{l}0.456 \\
(1.34)\end{array}$ & $\begin{array}{l}0.474 \\
(1.41)\end{array}$ \\
\hline Father dead & & $\begin{array}{l}-3.225 \\
(-1.57)\end{array}$ & $\begin{array}{l}-3.497^{*} \\
(-1.74)\end{array}$ \\
\hline Mother dead & & $\begin{array}{l}0.797 \\
(0.49)\end{array}$ & $\begin{array}{l}1.067 \\
(0.66)\end{array}$ \\
\hline No. Adults & & $\begin{array}{l}0.062 \\
(0.11)\end{array}$ & $\begin{array}{l}0.202 \\
(0.35)\end{array}$ \\
\hline No. Kids & & $\begin{array}{l}-0.091 \\
(-0.20)\end{array}$ & $\begin{array}{l}0.042 \\
(0.10)\end{array}$ \\
\hline Log(expenditure) & & $\begin{array}{l}4.331 * * \\
(2.55)\end{array}$ & $\begin{array}{l}4.643 * * * \\
(2.89)\end{array}$ \\
\hline No. Teachers & & $\begin{array}{l}4.071 \\
(1.44)\end{array}$ & $\begin{array}{l}3.385 \\
(1.25)\end{array}$ \\
\hline No. Blackboards & & $\begin{array}{l}10.118^{*} \\
(1.84)\end{array}$ & $\begin{array}{l}11.376^{* * *} \\
(2.05)\end{array}$ \\
\hline Secondary school & & $\begin{array}{l}-2.573 \\
(-0.74)\end{array}$ & $\begin{array}{l}-2.592 \\
(-0.79)\end{array}$ \\
\hline Urban Area & & $\begin{array}{l}-4.117 \\
(-0.98)\end{array}$ & $\begin{array}{l}-4.071 \\
(-1.06)\end{array}$ \\
\hline No durables & $\begin{array}{l}-54.553 * * * \\
(-3.98)\end{array}$ & $\begin{array}{l}-45.419 * * \\
(-2.08)\end{array}$ & \\
\hline Uncertainty & $\begin{array}{l}-0.833 \\
(-1.46)\end{array}$ & $\begin{array}{l}-1.239 \\
(-1.03)\end{array}$ & $\begin{array}{l}-0.094 \\
(-0.15)\end{array}$ \\
\hline uncertainty $*$ no durables & $\begin{array}{l}2.630 * * * \\
(3.50)\end{array}$ & $\begin{array}{l}2.364 * * \\
(1.98)\end{array}$ & \\
\hline No savings & & & $\begin{array}{l}-81.165^{*} \\
(-1.86)\end{array}$ \\
\hline uncertainty $*$ no savings & & & $\begin{array}{l}4.411^{*} \\
(1.79)\end{array}$ \\
\hline Constant & $\begin{array}{l}18.687 \\
(1.58)\end{array}$ & $\begin{array}{l}-136.008^{* * * *} \\
(-5.63)\end{array}$ & $\begin{array}{l}-161.717 * * * \\
(-6.97)\end{array}$ \\
\hline standard error of the regression (sigma) & $\begin{array}{l}22.859 * * * \\
(30.83)\end{array}$ & $\begin{array}{l}19.079 * * * \\
(29.10)\end{array}$ & $\begin{array}{l}19.133 * * * \\
(28.77)\end{array}$ \\
\hline
\end{tabular}

Notes: Observations: 990. Month of the interview and community dummies are added in all models. Robust $\mathrm{t}$ statistics in parentheses. $* * *, * * *$ significant at $10 \% ; 5 \%$ and $1 \%$, respectively. 